\title{
WATER QUALITY INDEX IN TWO LAND USE SITUATIONS IN THE MANTIQUEIRA RANGE
}

\author{
Índice de qualidade de água em duas situações de uso do solo na Serra da Mantiqueira
}

\author{
Leandro Campos Pinto ${ }^{1}$, Carlos Rogério de Mello², Daniel Furtado Ferreira ${ }^{3}$, Léo Fernandes Ávila²
}

\begin{abstract}
RESUMO
A utilização de um grande número de indicadores de qualidade de água torna oneroso o monitoramento dos corpos hídricos a longo tempo. Nesse sentido, a Análise de Componentes Principais (ACP) pode ser considerada como uma técnica promissora de grande auxílio na gestão dos recursos hídricos, pois permite diminuir a dimensionalidade dos dados, facilitando a sua análise. Neste estudo, objetivou-se obter um índice de qualidade de água (IQA) para a região das nascentes do Rio Grande, na Serra da Mantiqueira, Minas Gerais. Na composição do IQA, foi realizada a normalização dos resultados de indicadores de qualidade de água advindos de uma sub-bacia sob a Mata Atlântica e outra predominantemente sob pastagem. Esses valores normalizados foram submetidos a uma ACP e, posteriormente, foi efetuado o cálculo do IQA. Os indicadores com maiores pesos, segundo a ACP, foram o coliforme total, nitrato, coliforme termotolerante, demanda química de oxigênio e temperatura. A sub-bacia sob Mata Atlântica apresentou os melhores resultados de IQA, denotando a importância desse tipo de ambiente na manutenção da qualidade da água dos mananciais na região da Serra da Mantiqueira.
\end{abstract}

Termos de indexação: Mata Atlântica, nascentes, indicadores ambientais, análise de componentes principais.

\begin{abstract}
The use of a large number of water quality indicators increases the costs of streamflow monitoring throughout the time. Principal Component Analysis (PCA) can be considered a promised tool for water resources management, allowing a reduction in the dimensionality of the data and facilitating their analyses. This study aimed to obtain a water quality index (WQI) to characterize the Mantiqueira Range region. Water quality indicators from a sub-basin entirely occupied by Atlantic Forest and from another predominantly occupied by pasture were normalized and used to compose the WQI. The normalized values were submitted to a PCA evaluation and the WQI was then calculated. The Indicators with greatest weight, according to the PCA, were total coliform, nitrate, fecal coliform, chemical oxygen demand and temperature. The Atlantic forest sub-basin presented the best WQI results, demonstrating the importance of the forested environment in the maintenance of water quality in springs of the Mantiqueira Range region.
\end{abstract}

Index terms: Atlantic Forest, springs, environmental indicators, principal components analysis.

(Received in january 15, 2013 and approved in may 3, 2013)

\section{INTRODUCTION}

Economic and technological growth has been generating many unbalances in the environment which are reflected in a series of natural ecosystem alterations. Due to this, there is great worldwide concern regarding the availability and preservation of natural resources, especially water, seeking their sustainable management.

The area of the Mantiqueira Mountain Range is notable for being of extreme economic and environmental importance. According to Menezes et al. (2009) and Mello et al. (2008), the climatic characteristics of the area, with a positive annual water balance, in other words, the precipitation considerably surpassing evapotranspiration, causes the region to make up an important water production reference, with high drainage base generation potential (subterranean), with the source of rivers important for the Southeast of Brazil.

Pinto et al. (2009), evaluating the water quality of the Lavrinha Stream Watershed, in the region of the Mantiqueira Range, MG through WQI proposed by "Minas Gerais State Water Resources Institute" (IGAM), verified that the elevation of the thermotolerant coliform values was decisive for the water quality level in the watershed.

According to Zimmerman, Guimarães and PeraltaZamora (2008), in water quality studies, a great number of physiochemical and microbiological indicators are usually involved. Due to the fact that this high quantity of information presents different units of measurement, there

\footnotetext{
${ }^{1}$ Universidade Federal de Lavras/UFLA - Departamento de Ciência do Solo/DCS - Cx.P. 3037 - 37200-000 - Lavras - MG - Brasil leandcampos@yahoo.com.br

2Universidade Federal de Lavras/UFLA - Departamento de Engenharia/DEG - Lavras - MG - Brasil

${ }^{3}$ Universidade Federal de Lavras/UFLA - Departamento de Ciências Exatas/DEX - Lavras - MG - Brasil
}

Ciênc. agrotec., Lavras, v. 37, n. 4, p. 338 - 342, jul./ago., 2013 
is the need to adimensionalize the data as a function of the statistical parameters of a sample. In this sense, PCA can be considered as a compression technique, allowing to reduce the dimensionality of the data matrix and, which results in a lower number of principal components explaining most of the variance of the source data, without relevant loss of information (ZIMMERMAN; GUIMARÃES; PERALTA ZAMORA, 2008).

Nunes, Silva and Almeida (2003) mention that PCA is probably the most thoroughly used technique in geological and biological studies involving multivariate analyses. The WQI estimate, treated in the scope of PCA based analysis, can be a good proposal to be investigated, especially because PCA acts analyzing and characterizing the most important indicators and their respective weights. Therefore, the application of PCA allows to characterize the different weights of each one of the indicators in the Water Quality Index calculation (WQI), thus enabling to generate a specific WQI for the conditions of the Mantiqueira Range.

As such, this study sought to apply the principal component technique to identify the participation of the water quality indicators in the composition of a water quality index in two soil use situations (Atlantic Forest and pasture) in the Mantiqueira Mountain Range.

\section{MATERIAL AND METHODS}

The monitored area is inserted in the Lavrinha Stream Watershed (LSW), which is located in the region of the Mantiqueira Mountain Range (Figure 1), nearby of municipal district of Bocaina de Minas, Minas Gerais State. According to Mello et al. (2012), the region presents an average annual rainfall of $2100 \mathrm{~mm}$, with predominance of the $\mathrm{Cwb}$ climatic type, as classified by Köppen. The average annual temperature is $18^{\circ} \mathrm{C}$, with the average minimum under $11^{\circ} \mathrm{C}$ in the winter (from May to September) and average maximum $21^{\circ} \mathrm{C}$ in the summer (from November to March). More than $80 \%$ of the annual rainfall occurs in the summer, especially, between the months of December and March.

In the composition of the Water Quality Index (WQI), water quality indicator data from two sub-basin occupied by Atlantic Forest (SBAF) and Pasture (SBPA), in the stream Lavrinha Watershed were used.

The samples were collected at a central point of the transverse section of the respective bodies of water, for the "in situ" analyses as well as for the laboratory analyses. The collection, preservation and analysis procedures for the samples were based on the guide of the Standard of Methods, $19^{\text {th }}$ Edition (AMERICAN PUBLIC HEALTH ASSOSCIATION-APHA, 1995).

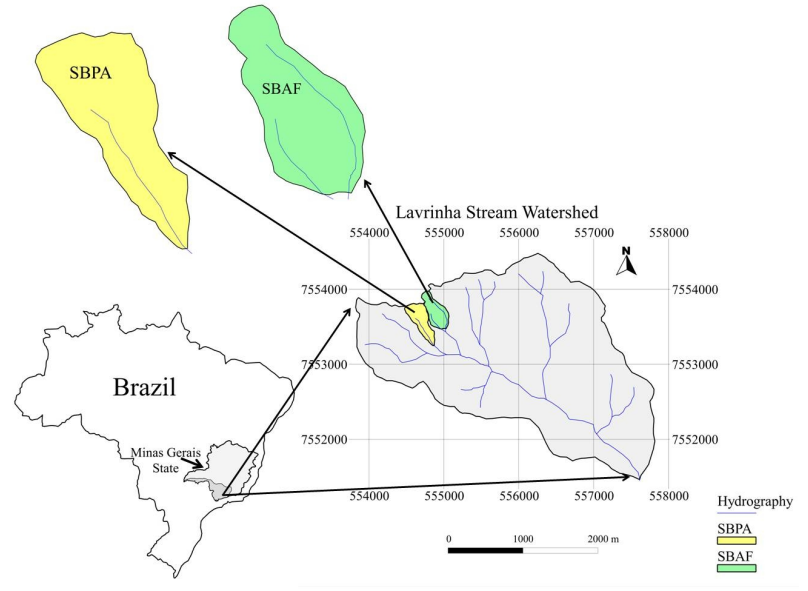

Figure 1 - Geographical location of Ribeirão Lavrinha Watershed, in the Mantiqueira Range, and monitored subbasins.

In order to describe the behavior of the bodies of water during the climatic seasons, the samplings took place throughout 1 (one) year, in both sub-basins, in the period from June, 2010 to May, 2011, totaling 10 samplings in each study area.

The following water quality indicators were analyzed: turbidity (NTU), pH, electrical conductivity (EC), total dissolved solids (TDS), dissolved oxygen (DO), temperature $(\mathrm{T})$, nitrate $\left(\mathrm{NO}_{3}\right)$, phosphate $\left(\mathrm{PO}_{4}\right)$, biochemical oxygen demand (BOD), chemical oxygen demand (COD), total coliforms (TC) and thermotolerant coliforms (FC), besides the monitoring of the discharge of the streams.

Previously to the WQI determination, the normalization of the indicators was conducted due to the fact that they present units of different measurements and the need to consider each quality indicator within its respective bulk data, considering the basic statistical characteristics associated to them. The normalized scoring function, developed by Wymore (1993), was applied to obtain the normalized values of the indicators, varying from zero to one, according to equation 1 .

$$
v(x, B, L, S)=\frac{1}{1+\left[\left(\frac{B-L}{x-L}\right)^{2 \cdot S(B+x-2 \cdot L)}\right]}
$$

in $v$ which $<$ is the normalized score; $\mathrm{B}$ the value of the indicator is when the normalized score $(<)$ is 0.5 ; $\mathrm{L}$ is the 
lower limit of the indicator; $S$ is the inclination from the straight line tangent to the curve in $\mathrm{B}$ and was determined equating the second derivative of Equation 1 to zero and $x$ is the normalized value of the water quality indicators (ALVARENGA, 2012).

The normalized values of the water quality indicators of the Mantiqueira Range were divided by the respective discharge values relative to the period and study place and later, submitted to a PCA. This was conducted due to the fact that the sub-basins present different hydrological behavior in terms of the drainage, with the SBAF presenting much higher discharge values during the year.

The multivariate statistical analysis was conducted using the SAS statistical program for Windows, version 9.3. From the analysis we produced matrices of correlation between the indicators and eigenvalues relative to the twelve components, as well as a group of eigenvectors proportional to the contribution of each indicator in the respective components.

From the first principal component analysis ( $\left.\mathrm{PCA}_{1}\right)$, the indicators that most contributed to the data variation and their respective weights were defined. Later, a second principal component analysis ( $\mathrm{PCA}_{2}$ ) of the indicators selected by $\mathrm{PCA}_{1}$ was conducted for the final determination of the weights of those indicators.

We adopted, as a criterion for selection of indicators that most contributed to the data variation, those having a value above 0.30 in the $\mathrm{PC}_{1}$ column (Table 1). Having the selected indicators, a second multivariate analysis $\left(\mathrm{PCA}_{2}\right)$ of the data was conducted for the acquisition of the weights of these indicators and WQI reformulation. To assign weights to each water quality indicator, relied on the results obtained in the $\mathrm{PCA}_{2}$. In this procedure are used the eigenvalues of the component $\left(\mathrm{PC}_{2}\right)$, raising the column values of $\mathrm{PC}_{2}$ squared. Those weights were applied to the WQI calculation, using the structure of equation 2 .

IQA $=\sum_{\mathrm{i}=1}^{\mathrm{n}} \mathrm{v}_{\mathrm{i}} \cdot \mathrm{PC}_{\mathrm{i}}$

In which $v_{i}$ is the normalized value of the indicator $i$ and $P C_{i}$ is the weight of indicator $i$ derived from $\mathrm{PCA}_{2}$.

The WQI for the structure of equation 2 varies from 0 (zero) to 1 (one), values close to 1 (a) indicate a good water quality and values close to 0 (zero) indicate low water quality.

\section{RESULTS AND DISCUSSION}

In table 1 the coefficients of the first component of the PCA $\mathrm{P}_{1}$ structure are shown as well as the weights of each water quality indicator. From the results of the statistical analysis, it was verified that in the set of eigenvectors proportional to the contribution of each indicator, the first principal component $\left(\mathrm{PC}_{1}\right)$ of $\mathrm{PCA}_{1}$ explains $93.07 \%$ of the variance of the source data, and may be used in the selection of indicators that most influenced the variation of the data. Girão et al. (2007), selecting water quality indicators in Rio Jaibaras using PCA, obtained as results, that the first and the second principal components, for a monitoring point, explained respectively, $57.28 \%$ and $24.05 \%$ of the total variance of the data, concentrating $81.33 \%$ of the information in two dimensions.

According to table 1 it is therefore verified that by the first component of the $\mathrm{PCA}_{1}$, the most significant indicators in the data variation were: $\mathrm{TC}, \mathrm{NO}_{3}, \mathrm{FC}, \mathrm{COD}$ and T. Dissolved oxygen, phosphate, turbidity and BOD are indicators that still have a significant weight in the variation of the data, but they were not used for the WQI calculation in this study.

Table 1 - Coefficients of the first component of the PCA structure.

\begin{tabular}{cc}
\hline Indicator & $\mathrm{PC}_{1}$ \\
\hline NTU & 0.23 \\
pH & 0.14 \\
EC & 0.12 \\
TDS & 0.13 \\
DO & 0.27 \\
T & $0.31 *$ \\
NO3 & $0.43^{*}$ \\
PO4 & 0.26 \\
BOD & 0.22 \\
COD & $0.33^{*}$ \\
TC & $0.43^{*}$ \\
FC & $0.36^{*}$ \\
\hline Explained variance & $93.07 \%$ \\
*Components that contributed most variation in the data.
\end{tabular}

Andrade et al. (2005) analyzing the quality of streams in the Alto Acaraú basin, Ceará state verified that the use of Factor Analysis/Principal Component Analysis (FA/PCA), promoted the reduction of 16 indicators of water quality of the Acaraú river basin to 6 , which explained $88 \%$ of the total variance. These results demonstrate the 
functionality of the PCA technique in the context of environmental hydrology, specifically in the analysis of water quality.

It can be verified in table 2 that 5 water quality indicators were selected ( $\mathrm{TC}, \mathrm{NO}_{3}, \mathrm{FC}, \mathrm{COD}$ and $\left.\mathrm{T}\right)$ that most contributed to the data variation (value above 0.30 in the $\mathrm{PC}_{1}$ column). This allowed to characterize that, for the environment of the Mantiqueira Range, the monitoring of the prominent indicators should be favored so that the quality of the regional waters can be characterized, aiding in future water resource administration plans in the region area of the Mantiqueira Range.

Table $2-\mathrm{PCA}_{2}$ coefficients and respective weights of each water quality indicator.

\begin{tabular}{ccc}
\hline Indicator & $\mathrm{PC}_{2}$ & $\left(\mathrm{PC}_{2}\right)^{2}=$ Weight \\
\hline $\mathrm{TC}$ & 0.51 & 0.26 \\
$\mathrm{NO}_{3}$ & 0.51 & 0.26 \\
$\mathrm{FC}$ & 0.42 & 0.18 \\
$\mathrm{COD}$ & 0.40 & 0.16 \\
$\mathrm{~T}$ & 0.37 & 0.14 \\
\hline Explained variance & $96.61 \%$ & $\Sigma=1$ \\
\hline
\end{tabular}

Analyzing the data of figure 2, it can be observed that the Water Quality Index for the Mantiqueira Range conditions demonstrated better behavior for the Atlantic Forest conditions. Even according to the table and above mentioned figure, the Water Quality Index remained high in the months of little precipitation, evidencing that the surface runoff is one of the possible causes of the water quality alteration and that the soil use is fundamental in this aspect. In the month of April of 2011, even with low total precipitation, the WQI of the Pasture remained low and that was the month where the highest WQI distinction between the two monitored sub-basins occurred. This WQI behavior is due to the previous precipitation, where the beginning of the month of April was preceded by an atypical period of high precipitation, which reduced the WQI values of the pasture environment gradually by the carrying off of eroded soil due to lower soil protection by the pasture. This effect did not happen in an accentuated way in SBAF due to the mitigating effect of the forest in the context of the generation of the direct surface runoff and flood flow, as demonstrated by Mello et al. (2008).

Still analyzing figure 2, a WQI decline is observed at the beginning of the rainy period (November of 2010), for both sub-basins and a higher resilience of SBAF as to the WQI values, in other words, its reduction is influenced by the presence of the Atlantic Forest. SBPA has its WQI values reduced due to the hydrological phenomena associated to surface runoff as a result of less rain interception and consequently higher soil exposure.

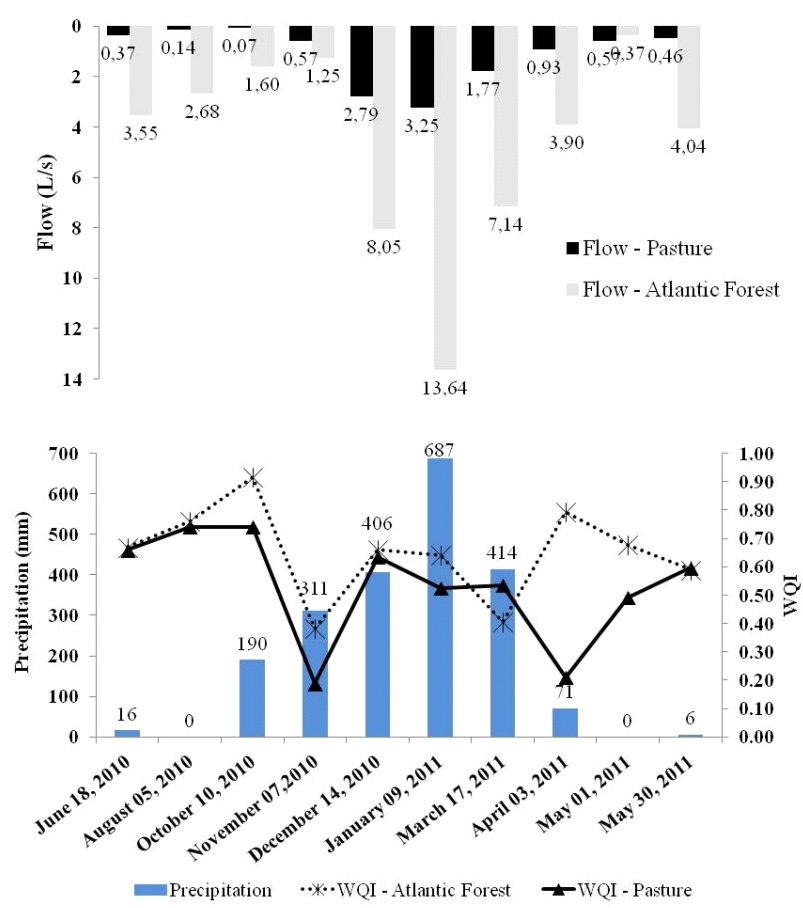

Figure 2 - WQI values calculated based on the methodology proposed in this study for the two environments in the Mantiqueira Mountain Range and their respective rainfall and flow of the streams.

Therefore, the environment under the Atlantic Forest maintained higher WQI values, even in higher precipitation periods, evidencing that this type of environment offers better protection from the direct impact of drops from more intense rains and, consequently, from the generation of the surface runoff and maintenance of the water quality in the Mantiqueira Range environment.

\section{CONCLUSIONS}

The application of PCA reduced the number of water quality indicators used in the WQI calculation.

Total coliforms, nitrate, thermotolerant coliforms, COD and temperature were the principal water quality indicators that influenced the WQI composition proposed in this study. 
The water quality indexes of the sub-basin with Atlantic Forest presented better results in comparison with the sub-basin with pasture, proving the importance of the regional native forests for the water quality maintenance of the streams.

\section{ACKNOWLEDGEMENT}

The authors thank CNPq, FAPEMIG and Cemig/ Aneel, for financial support and research and study scholarships for the authors.

\section{REFERENCES}

ALVARENGA, C.C. Índice de qualidade do solo associado à recarga de água subterrânea (IQS RA) na Bacia Hidrográfica do Alto Rio Grande, MG. Revista Brasileira de Ciência do Solo, Viçosa, v. 36, p. 16081619, 2012.

AMERICAN PUBLIC HEALTHASSOCIATION-APHA. Standard methods for the examination of water and wastewater. Washington: American Water Works Association Environment Federation, 1995.

ANDRADE, E.M. et al. Índice de qualidade de água, uma proposta para o vale do rio Trussu, Ceará. Revista Ciência Agronômica, Fortaleza, v.36, p.135-142, 2005.

GIRÃO, E. G. et al. Seleção dos indicadores da qualidade de água no Rio Jaibaras pelo emprego da análise da componente principal. Revista Ciência Agronômica, Fortaleza, v.38, n.1, p.17-24, 2007.

MELLO, C. R. et al. Sea surface temperature (SST) and rainfall erosivity in the Upper Grande River Basin,
Southeast Brazil. Ciência e Agrotecnologia, Lavras, v.36, p.53-59, 2012.

MELLO, C.R. et al. Development and application of a simple hydrologic model simulation for a Brazilian headwater basin. Catena, Amsterdam, v.75, p.235-247, 2008.

MENEZES, M. D. et al. Dinâmica hidrológica de duas nascentes, associada ao uso do solo, características pedológicas e atributos físico-hídricos na sub-bacia hidrográfica do Ribeirão Lavrinha - Serra da Mantiqueira (MG). Scientia Forestalis, Piracicaba, v.37, n.82, p. 175184, jun, 2009.

NUNES, M.L.; SILVA, E.F.; ALMEIDA, S.F.P.

Assessment of water quality in the Caima and Mau river basins (Portugal) using geochemical and biological indices. Water, Air, and Soil Pollution, Ontario, v.150, p.227-250, 2003.

PINTO, D.B.F. et al. Qualidade da água do ribeirão Lavrinha na região Alto Rio Grande-MG, Brasil. Ciência e Agrotecnologia, Lavras, v.33, n.4, p.1145-1152, 2009.

WYMORE, A.W. Model-based systems engineering. Boca Raton, 2008.

ZIMMERMANN, C.M.; GUIMARÃES, O.M.; PERALTA-ZAMORA, P.G. Avaliação da qualidade do corpo hídrico do rio Tibagi na região de Ponta Grossa utilizando análise de componentes principais (PCA). Química Nova, São Paulo, v.31, p.1727-1732, 2008. 